\title{
OECD Principles of Corporate Governance
}

\section{$\operatorname{OECD} \ll \bigcirc$}

2004 
(c) OECD, 2004

(C) Software: 1987-1996, Acrobat is a trademark of ADOBE.

All rights reserved. OECD grants you the right to use one copy of this Program for your personal use only. Unauthorised reproduction, lending, hiring, transmission or distribution of any data or software is prohibited. You must treat the Program and associated materials and any elements thereof like any other copyrighted material.

All requests should be made to:

Head of Publications Service,

OECD Publications Service,

2, rue André-Pascal,

75775 Paris Cedex 16, France. 


\section{OECD Principles of Corporate Governance}

\section{4}




\section{ORGANISATION FOR ECONOMIC CO-OPERATION AND DEVELOPMENT}

Pursuant to Article 1 of the Convention signed in Paris on 14th December 1960, and which came into force on 30th September 1961, the Organisation for Economic Co-operation and Development (OECD) shall promote policies designed:

- to achieve the highest sustainable economic growth and employment and a rising standard of living in member countries, while maintaining financial stability, and thus to contribute to the development of the world economy;

- to contribute to sound economic expansion in member as well as non-member countries in the process of economic development; and

- to contribute to the expansion of world trade on a multilateral, non-discriminatory basis in accordance with international obligations.

The original member countries of the OECD are Austria, Belgium, Canada, Denmark, France, Germany, Greece, Iceland, Ireland, Italy, Luxembourg, the Netherlands, Norway, Portugal, Spain, Sweden, Switzerland, Turkey, the United Kingdom and the United States. The following countries became members subsequently through accession at the dates indicated hereafter: Japan (28th April 1964), Finland (28th January 1969), Australia (7th June 1971), New Zealand (29th May 1973), Mexico (18th May 1994), the Czech Republic (21st December 1995), Hungary (7th May 1996), Poland (22nd November 1996), Korea (12th December 1996) and the Slovak Republic (14th December 2000). The Commission of the European Communities takes part in the work of the OECD (Article 13 of the OECD Convention).

Publié en français sous le titre :

Principes de gouvernement d'entreprise de l'OCDE

2004

(c) OECD 2004

Permission to reproduce a portion of this work for non-commercial purposes or classroom use should be obtained through the Centre français d'exploitation du droit de copie (CFC), 20, rue des Grands-Augustins, 75006 Paris, France, tel. (33-1) 44074770 , fax (33-1) 463467 19, for every country except the United States. In the United States permission should be obtained through the Copyright Clearance Center, Customer Service, (508)750-8400, 222 Rosewood Drive, Danvers, MA 01923 USA, or CCC Online: www.copyright.com. All other applications for permission to reproduce or translate all or part of this book should be made to OECD Publications, 2, rue André-Pascal, 75775 Paris Cedex 16, France. 


\section{Foreword}

The OECD Principles of Corporate Governance were endorsed by OECD Ministers in 1999 and have since become an international benchmark for policy makers, investors, corporations and other stakeholders worldwide. They have advanced the corporate governance agenda and provided specific guidance for legislative and regulatory initiatives in both OECD and non OECD countries. The Financial Stability Forum has designated the Principles as one of the 12 key standards for sound financial systems. The Principles also provide the basis for an extensive programme of cooperation between OECD and non-OECD countries and underpin the corporate governance component of World Bank/IMF Reports on the Observance of Standards and Codes (ROSC).

The Principles have now been thoroughly reviewed to take account of recent developments and experiences in OECD member and non-member countries. Policy makers are now more aware of the contribution good corporate governance makes to financial market stability, investment and economic growth. Companies better understand how good corporate governance contributes to their competitiveness. Investors - especially collective investment institutions and pension funds acting in a fiduciary capacity - realise they have a role to play in ensuring good corporate governance practices, thereby underpinning the value of their investments. In today's economies, interest in corporate governance goes beyond that of shareholders in the performance of individual companies. As companies play a pivotal role in our economies and we rely increasingly on private sector institutions to manage personal savings and secure retirement incomes, good corporate governance is important to broad and growing segments of the population.

The review of the Principles was undertaken by the OECD Steering Group on Corporate Governance under a mandate from OECD Ministers in 2002. The review was supported by a comprehensive survey of how member countries addressed the different corporate governance challenges they faced. It also drew on experiences in economies outside the OECD area where the OECD, in co-operation with the World Bank and other sponsors, 
organises Regional Corporate Governance Roundtables to support regional reform efforts.

The review process benefited from contributions from many parties. Key international institutions participated and extensive consultations were held with the private sector, labour, civil society and representatives from non-OECD countries. The process also benefited greatly from the insights of internationally recognised experts who participated in two high level informal gatherings I convened. Finally, many constructive suggestions were received when a draft of the Principles was made available for public comment on the internet.

The Principles are a living instrument offering non-binding standards and good practices as well as guidance on implementation, which can be adapted to the specific circumstances of individual countries and regions. The OECD offers a forum for ongoing dialogue and exchange of experiences among member and non-member countries. To stay abreast of constantly changing circumstances, the OECD will closely follow developments in corporate governance, identifying trends and seeking remedies to new challenges.

These Revised Principles will further reinforce OECD's contribution and commitment to collective efforts to strengthen the fabric of corporate governance around the world in the years ahead. This work will not eradicate criminal activity, but such activity will be made more difficult as rules and regulations are adopted in accordance with the Principles.

Importantly, our efforts will also help develop a culture of values for professional and ethical behaviour on which well functioning markets depend. Trust and integrity play an essential role in economic life and for the sake of business and future prosperity we have to make sure that they are properly rewarded.

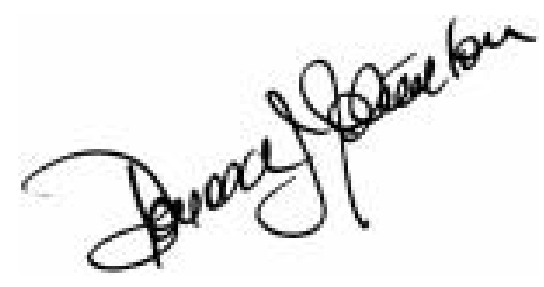

Donald J. Johnston

OECD Secretary-General 


\section{ACKNOWLEDGEMENTS}

I would like to express my appreciation to members of the Steering Group and its Chair, Ms. Veronique Ingram, whose dedication and expertise made it possible to complete the review so effectively in a short period of time. I would also thank all those officials and experts from around the world who participated in our consultations, submitted comments or otherwise contributed to ensuring the continued relevance of the OECD Principles of Corporate Governance in changing times.

Special thanks are due to Ira Millstein and Sir Adrian Cadbury who have contributed so much since OECD's corporate governance work first began and indeed to all the participants in the two high level gatherings I convened in Paris and other distinguished experts who contributed to the review, including: Susan Bies, Susan Bray, Ron Blackwell, Alain-Xavier Briatte, David Brown, Luiz Cantidiano, Maria Livanos Cattaui, Peter Clifford, Andrew Crockett, Stephen Davis, Peter Dey, Carmine Di Noia, John Evans, Jeffrey Garten, Leo Goldschmidt, James Grant, Gerd Häusler, Tom Jones, Stephen Joynt, Erich Kandler, Michael Klein, Igor Kostikov, Daniel Lebegue, Jean-François Lepetit, Claudine Malone, Teruo Masaki, Il-Chong Nam, Taiji Okusu, Michel Pebereau, Caroline Phillips, Patricia Peter, John Plender, Michel Prada, Iain Richards, Alastair Ross Goobey, Albrecht Schäfer, Christian Schricke, Fernando Teixeira dos Santos, Christian Strenger, Barbara Thomas, Jean-Claude Trichet, Tom Vant, Graham Ward, Edwin Williamson, Martin Wassell, Peter Woicke, David Wright and Eddy Wymeersch.

In addition to participants from all OECD countries, the OECD Steering Group on Corporate Governance includes regular observers from the World Bank, the International Monetary Fund (IMF) and the Bank for International Settlements (BIS). For the purpose of the review of the Principles, the Financial Stability Forum (FSF), the Basel Committee on Banking Supervision, and the International Organization of Securities Commissions (IOSCO) were invited as ad hoc observers.

I am also pleased to acknowledge the constructive contributions of the OECD's Business and Industry Advisory Committee (BIAC) and the Trade Union Advisory Committee (TUAC) whose representatives participated actively throughout the review process, including the regular meetings of the Steering Group.

Finally, I thank the OECD Secretariat staff in the Directorate for Financial and Enterprise Affairs who devoted long hours to serve the Steering Group with dedication and excellence: William Witherell, Rainer Geiger, Rinaldo Pecchioli, Robert Ley, Mats Isaksson, Grant Kirkpatrick, Alessandro Goglio, Laura Holliday and other members of the Corporate Affairs Division. 

Table of Contents

Preamble 11

\section{Part One \\ The OECD Principles of Corporate Governance}

I. Ensuring the Basis for an Effective Corporate Governance Framework............ 17

II. The Rights of Shareholders and Key Ownership Functions................................ 18

III. The Equitable Treatment of Shareholders............................................................ 20

IV. The Role of Stakeholders in Corporate Governance ..........................................2

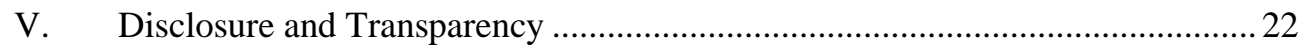

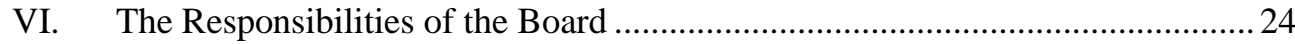

\section{Part Two \\ Annotations to the OECD Principles of Corporate Governance}

I. Ensuring the Basis for an Effective Corporate Governance Framework............29

II. The Rights of Shareholders and Key Ownership Functions............................... 32

III. The Equitable Treatment of Shareholders ........................................................... 40

IV. The Role of Stakeholders in Corporate Governance ........................................... 46

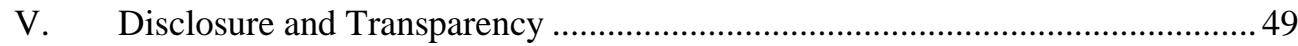

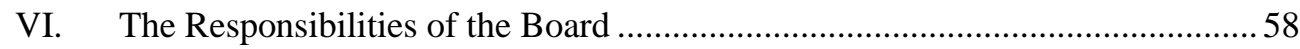





\section{OECD Principles of Corporate Governance}

The OECD Principles of Corporate Governance were originally developed in response to a call by the OECD Council Meeting at Ministerial level on 27-28 April 1998, to develop, in conjunction with national governments, other relevant international organisations and the private sector, a set of corporate governance standards and guidelines. Since the Principles were agreed in 1999, they have formed the basis for corporate governance initiatives in both OECD and non-OECD countries alike. Moreover, they have been adopted as one of the Twelve Key Standards for Sound Financial Systems by the Financial Stability Forum. Accordingly, they form the basis of the corporate governance component of the World Bank/IMF Reports on the Observance of Standards and Codes (ROSC).

The OECD Council Meeting at Ministerial Level in 2002 agreed to survey developments in OECD countries and to assess the Principles in light of developments in corporate governance. This task was entrusted to the OECD Steering Group on Corporate Governance, which comprises representatives from OECD countries. In addition, the World Bank, the Bank for International Settlements (BIS) and the International Monetary Fund (IMF) were observers to the Group. For the assessment, the Steering Group also invited the Financial Stability Forum, the Basel Committee, and the International Organization of Securities Commissions (IOSCO) as ad hoc observers.

In its review of the Principles, the Steering Group has undertaken comprehensive consultations and has prepared with the assistance of members the Survey of Developments in OECD Countries. The consultations have included experts from a large number of countries which have participated in the Regional Corporate Governance Roundtables that the OECD organises in Russia, Asia, South East Europe, Latin America and Eurasia with the support of the Global Corporate Governance Forum and others, and in co-operation with the World Bank and other non-OECD countries as well. Moreover, the Steering Group has consulted a wide range of interested parties such as the business sector, investors, professional groups at national and international levels, trade unions, civil society organisations and international standard setting bodies. A draft version of 
the Principles was put on the OECD website for public comment and resulted in a large number of responses. These have been made public on the OECD web site.

On the basis of the discussions in the Steering Group, the Survey and the comments received during the wide ranging consultations, it was concluded that the 1999 Principles should be revised to take into account new developments and concerns. It was agreed that the revision should be pursued with a view to maintaining a non-binding principles-based approach, which recognises the need to adapt implementation to varying legal economic and cultural circumstances. The revised Principles contained in this document thus build upon a wide range of experience not only in the OECD area but also in non-OECD countries. 


\section{Preamble}

The Principles are intended to assist OECD and non-OECD governments in their efforts to evaluate and improve the legal, institutional and regulatory framework for corporate governance in their countries, and to provide guidance and suggestions for stock exchanges, investors, corporations, and other parties that have a role in the process of developing good corporate governance. The Principles focus on publicly traded companies, both financial and non-financial. However, to the extent they are deemed applicable, they might also be a useful tool to improve corporate governance in non-traded companies, for example, privately held and stateowned enterprises. The Principles represent a common basis that OECD member countries consider essential for the development of good governance practices. They are intended to be concise, understandable and accessible to the international community. They are not intended to substitute for government, semi-government or private sector initiatives to develop more detailed "best practice" in corporate governance.

Increasingly, the OECD and its member governments have recognised the synergy between macroeconomic and structural policies in achieving fundamental policy goals. Corporate governance is one key element in improving economic efficiency and growth as well as enhancing investor confidence. Corporate governance involves a set of relationships between a company's management, its board, its shareholders and other stakeholders. Corporate governance also provides the structure through which the objectives of the company are set, and the means of attaining those objectives and monitoring performance are determined. Good corporate governance should provide proper incentives for the board and management to pursue objectives that are in the interests of the company and its shareholders and should facilitate effective monitoring. The presence of an effective corporate governance system, within an individual company and across an economy as a whole, helps to provide a degree of confidence that is necessary for the proper functioning of a market economy. As a result, the cost of capital is lower and firms are encouraged to use resources more efficiently, thereby underpinning growth. 
Corporate governance is only part of the larger economic context in which firms operate that includes, for example, macroeconomic policies and the degree of competition in product and factor markets. The corporate governance framework also depends on the legal, regulatory, and institutional environment. In addition, factors such as business ethics and corporate awareness of the environmental and societal interests of the communities in which a company operates can also have an impact on its reputation and its long-term success.

While a multiplicity of factors affect the governance and decisionmaking processes of firms, and are important to their long-term success, the Principles focus on governance problems that result from the separation of ownership and control. However, this is not simply an issue of the relationship between shareholders and management, although that is indeed the central element. In some jurisdictions, governance issues also arise from the power of certain controlling shareholders over minority shareholders. In other countries, employees have important legal rights irrespective of their ownership rights. The Principles therefore have to be complementary to a broader approach to the operation of checks and balances. Some of the other issues relevant to a company's decision-making processes, such as environmental, anti-corruption or ethical concerns, are taken into account but are treated more explicitly in a number of other OECD instruments (including the Guidelines for Multinational Enterprises and the Convention on Combating Bribery of Foreign Public Officials in International Transactions) and the instruments of other international organisations.

Corporate governance is affected by the relationships among participants in the governance system. Controlling shareholders, which may be individuals, family holdings, bloc alliances, or other corporations acting through a holding company or cross shareholdings, can significantly influence corporate behaviour. As owners of equity, institutional investors are increasingly demanding a voice in corporate governance in some markets. Individual shareholders usually do not seek to exercise governance rights but may be highly concerned about obtaining fair treatment from controlling shareholders and management. Creditors play an important role in a number of governance systems and can serve as external monitors over corporate performance. Employees and other stakeholders play an important role in contributing to the long-term success and performance of the corporation, while governments establish the overall institutional and legal framework for corporate governance. The role of each of these participants and their interactions vary widely among OECD countries and among nonOECD countries as well. These relationships are subject, in part, to law and regulation and, in part, to voluntary adaptation and, most importantly, to market forces. 
The degree to which corporations observe basic principles of good corporate governance is an increasingly important factor for investment decisions. Of particular relevance is the relation between corporate governance practices and the increasingly international character of investment. International flows of capital enable companies to access financing from a much larger pool of investors. If countries are to reap the full benefits of the global capital market, and if they are to attract long-term "patient" capital, corporate governance arrangements must be credible, well understood across borders and adhere to internationally accepted principles. Even if corporations do not rely primarily on foreign sources of capital, adherence to good corporate governance practices will help improve the confidence of domestic investors, reduce the cost of capital, underpin the good functioning of financial markets, and ultimately induce more stable sources of financing.

There is no single model of good corporate governance. However, work carried out in both OECD and non-OECD countries and within the Organisation has identified some common elements that underlie good corporate governance. The Principles build on these common elements and are formulated to embrace the different models that exist. For example, they do not advocate any particular board structure and the term "board" as used in this document is meant to embrace the different national models of board structures found in OECD and non-OECD countries. In the typical two tier system, found in some countries, "board" as used in the Principles refers to the "supervisory board" while "key executives" refers to the "management board". In systems where the unitary board is overseen by an internal auditor's body, the principles applicable to the board are also, mutatis mutandis, applicable. The terms "corporation" and "company" are used interchangeably in the text.

The Principles are non-binding and do not aim at detailed prescriptions for national legislation. Rather, they seek to identify objectives and suggest various means for achieving them. Their purpose is to serve as a reference point. They can be used by policy makers as they examine and develop the legal and regulatory frameworks for corporate governance that reflect their own economic, social, legal and cultural circumstances, and by market participants as they develop their own practices.

The Principles are evolutionary in nature and should be reviewed in light of significant changes in circumstances. To remain competitive in a changing world, corporations must innovate and adapt their corporate governance practices so that they can meet new demands and grasp new opportunities. Similarly, governments have an important responsibility for shaping an effective regulatory framework that provides for sufficient flexibility to allow markets to function effectively and to respond to 
expectations of shareholders and other stakeholders. It is up to governments and market participants to decide how to apply these Principles in developing their own frameworks for corporate governance, taking into account the costs and benefits of regulation.

The following document is divided into two parts. The Principles presented in the first part of the document cover the following areas: I) Ensuring the basis for an effective corporate governance framework; II) The rights of shareholders and key ownership functions; III) The equitable treatment of shareholders; IV) The role of stakeholders; V) Disclosure and transparency; and VI) The responsibilities of the board. Each of the sections is headed by a single Principle that appears in bold italics and is followed by a number of supporting sub-principles. In the second part of the document, the Principles are supplemented by annotations that contain commentary on the Principles and are intended to help readers understand their rationale. The annotations may also contain descriptions of dominant trends and offer alternative implementation methods and examples that may be useful in making the Principles operational. 
Part One

The OECD Principles of Corporate Governance 



\section{Ensuring the Basis for an Effective Corporate Governance Framework}

The corporate governance framework should promote transparent and efficient markets, be consistent with the rule of law and clearly articulate the division of responsibilities among different supervisory, regulatory and enforcement authorities.

A. The corporate governance framework should be developed with a view to its impact on overall economic performance, market integrity and the incentives it creates for market participants and the promotion of transparent and efficient markets.

B. The legal and regulatory requirements that affect corporate governance practices in a jurisdiction should be consistent with the rule of law, transparent and enforceable.

C. The division of responsibilities among different authorities in a jurisdiction should be clearly articulated and ensure that the public interest is served.

D. Supervisory, regulatory and enforcement authorities should have the authority, integrity and resources to fulfil their duties in a professional and objective manner. Moreover, their rulings should be timely, transparent and fully explained. 


\section{The Rights of Shareholders and Key Ownership Functions}

\section{The corporate governance framework should protect and facilitate the exercise of shareholders' rights.}

A. Basic shareholder rights should include the right to: 1) secure methods of ownership registration; 2) convey or transfer shares; 3) obtain relevant and material information on the corporation on a timely and regular basis; 4) participate and vote in general shareholder meetings; 5) elect and remove members of the board; and 6) share in the profits of the corporation.

B. Shareholders should have the right to participate in, and to be sufficiently informed on, decisions concerning fundamental corporate changes such as: 1) amendments to the statutes, or articles of incorporation or similar governing documents of the company; 2) the authorisation of additional shares; and 3) extraordinary transactions, including the transfer of all or substantially all assets, that in effect result in the sale of the company.

C. Shareholders should have the opportunity to participate effectively and vote in general shareholder meetings and should be informed of the rules, including voting procedures, that govern general shareholder meetings:

1. Shareholders should be furnished with sufficient and timely information concerning the date, location and agenda of general meetings, as well as full and timely information regarding the issues to be decided at the meeting.

2. Shareholders should have the opportunity to ask questions to the board, including questions relating to the annual external audit, to place items on the agenda of general meetings, and to propose resolutions, subject to reasonable limitations.

3. Effective shareholder participation in key corporate governance decisions, such as the nomination and election of board members, should be facilitated. Shareholders should be able to make their views known on the remuneration policy for board members and key executives. The equity component of compensation schemes for board members and employees should be subject to shareholder approval. 
4. Shareholders should be able to vote in person or in absentia, and equal effect should be given to votes whether cast in person or in absentia.

D. Capital structures and arrangements that enable certain shareholders to obtain a degree of control disproportionate to their equity ownership should be disclosed.

E. Markets for corporate control should be allowed to function in an efficient and transparent manner.

1. The rules and procedures governing the acquisition of corporate control in the capital markets, and extraordinary transactions such as mergers, and sales of substantial portions of corporate assets, should be clearly articulated and disclosed so that investors understand their rights and recourse. Transactions should occur at transparent prices and under fair conditions that protect the rights of all shareholders according to their class.

2. Anti-take-over devices should not be used to shield management and the board from accountability.

F. The exercise of ownership rights by all shareholders, including institutional investors, should be facilitated.

1. Institutional investors acting in a fiduciary capacity should disclose their overall corporate governance and voting policies with respect to their investments, including the procedures that they have in place for deciding on the use of their voting rights.

2. Institutional investors acting in a fiduciary capacity should disclose how they manage material conflicts of interest that may affect the exercise of key ownership rights regarding their investments.

G. Shareholders, including institutional shareholders, should be allowed to consult with each other on issues concerning their basic shareholder rights as defined in the Principles, subject to exceptions to prevent abuse. 


\section{The Equitable Treatment of Shareholders}

\section{The corporate governance framework should ensure the equitable treatment of all shareholders, including minority and foreign shareholders. All shareholders should have the opportunity to obtain effective redress for violation of their rights.}

A. All shareholders of the same series of a class should be treated equally.

1. Within any series of a class, all shares should carry the same rights. All investors should be able to obtain information about the rights attached to all series and classes of shares before they purchase. Any changes in voting rights should be subject to approval by those classes of shares which are negatively affected.

2. Minority shareholders should be protected from abusive actions by, or in the interest of, controlling shareholders acting either directly or indirectly, and should have effective means of redress.

3. Votes should be cast by custodians or nominees in a manner agreed upon with the beneficial owner of the shares.

4. Impediments to cross border voting should be eliminated.

5. Processes and procedures for general shareholder meetings should allow for equitable treatment of all shareholders. Company procedures should not make it unduly difficult or expensive to cast votes.

B. Insider trading and abusive self-dealing should be prohibited.

C. Members of the board and key executives should be required to disclose to the board whether they, directly, indirectly or on behalf of third parties, have a material interest in any transaction or matter directly affecting the corporation. 


\section{The Role of Stakeholders in Corporate Governance}

The corporate governance framework should recognise the rights of stakeholders established by law or through mutual agreements and encourage active co-operation between corporations and stakeholders in creating wealth, jobs, and the sustainability of financially sound enterprises.

A. The rights of stakeholders that are established by law or through mutual agreements are to be respected.

B. Where stakeholder interests are protected by law, stakeholders should have the opportunity to obtain effective redress for violation of their rights.

C. Performance-enhancing mechanisms for employee participation should be permitted to develop.

D. Where stakeholders participate in the corporate governance process, they should have access to relevant, sufficient and reliable information on a timely and regular basis.

E. Stakeholders, including individual employees and their representative bodies, should be able to freely communicate their concerns about illegal or unethical practices to the board and their rights should not be compromised for doing this.

F. The corporate governance framework should be complemented by an effective, efficient insolvency framework and by effective enforcement of creditor rights. 


\section{Disclosure and Transparency}

The corporate governance framework should ensure that timely and accurate disclosure is made on all material matters regarding the corporation, including the financial situation, performance, ownership, and governance of the company.

A. Disclosure should include, but not be limited to, material information on:

1. The financial and operating results of the company.

2. Company objectives.

3. Major share ownership and voting rights.

4. Remuneration policy for members of the board and key executives, and information about board members, including their qualifications, the selection process, other company directorships and whether they are regarded as independent by the board.

5. Related party transactions.

6. Foreseeable risk factors.

7. Issues regarding employees and other stakeholders.

8. Governance structures and policies, in particular, the content of any corporate governance code or policy and the process by which it is implemented.

B. Information should be prepared and disclosed in accordance with high quality standards of accounting and financial and non-financial disclosure.

C. An annual audit should be conducted by an independent, competent and qualified, auditor in order to provide an external and objective assurance to the board and shareholders that the financial statements fairly represent the financial position and performance of the company in all material respects.

D. External auditors should be accountable to the shareholders and owe a duty to the company to exercise due professional care in the conduct of the audit. 
E. Channels for disseminating information should provide for equal, timely and costefficient access to relevant information by users.

F. The corporate governance framework should be complemented by an effective approach that addresses and promotes the provision of analysis or advice by analysts, brokers, rating agencies and others, that is relevant to decisions by investors, free from material conflicts of interest that might compromise the integrity of their analysis or advice. 


\section{The Responsibilities of the Board}

The corporate governance framework should ensure the strategic guidance of the company, the effective monitoring of management by the board, and the board's accountability to the company and the shareholders.

A. Board members should act on a fully informed basis, in good faith, with due diligence and care, and in the best interest of the company and the shareholders.

B. Where board decisions may affect different shareholder groups differently, the board should treat all shareholders fairly.

C. The board should apply high ethical standards. It should take into account the interests of stakeholders.

D. The board should fulfil certain key functions, including:

1. Reviewing and guiding corporate strategy, major plans of action, risk policy, annual budgets and business plans; setting performance objectives; monitoring implementation and corporate performance; and overseeing major capital expenditures, acquisitions and divestitures.

2. Monitoring the effectiveness of the company's governance practices and making changes as needed.

3. Selecting, compensating, monitoring and, when necessary, replacing key executives and overseeing succession planning.

4. Aligning key executive and board remuneration with the longer term interests of the company and its shareholders.

5. Ensuring a formal and transparent board nomination and election process.

6. Monitoring and managing potential conflicts of interest of management, board members and shareholders, including misuse of corporate assets and abuse in related party transactions. 
7. Ensuring the integrity of the corporation's accounting and financial reporting systems, including the independent audit, and that appropriate systems of control are in place, in particular, systems for risk management, financial and operational control, and compliance with the law and relevant standards.

8. Overseeing the process of disclosure and communications.

E. The board should be able to exercise objective independent judgement on corporate affairs.

1. Boards should consider assigning a sufficient number of non-executive board members capable of exercising independent judgement to tasks where there is a potential for conflict of interest. Examples of such key responsibilities are ensuring the integrity of financial and non-financial reporting, the review of related party transactions, nomination of board members and key executives, and board remuneration.

2. When committees of the board are established, their mandate, composition and working procedures should be well defined and disclosed by the board.

3. Board members should be able to commit themselves effectively to their responsibilities.

F. In order to fulfil their responsibilities, board members should have access to accurate, relevant and timely information. 

Part Two

Annotations to the OECD Principles of Corporate Governance 



\section{Ensuring the Basis for an Effective Corporate Governance Framework}

\section{The corporate governance framework should promote transparent and efficient markets, be consistent with the rule of law and clearly articulate the division of responsibilities among different supervisory, regulatory and enforcement authorities.}

To ensure an effective corporate governance framework, it is necessary that an appropriate and effective legal, regulatory and institutional foundation is established upon which all market participants can rely in establishing their private contractual relations. This corporate governance framework typically comprises elements of legislation, regulation, selfregulatory arrangements, voluntary commitments and business practices that are the result of a country's specific circumstances, history and tradition. The desirable mix between legislation, regulation, self-regulation, voluntary standards, etc. in this area will therefore vary from country to country. As new experiences accrue and business circumstances change, the content and structure of this framework might need to be adjusted.

Countries seeking to implement the Principles should monitor their corporate governance framework, including regulatory and listing requirements and business practices, with the objective of maintaining and strengthening its contribution to market integrity and economic performance. As part of this, it is important to take into account the interactions and complementarity between different elements of the corporate governance framework and its overall ability to promote ethical, responsible and transparent corporate governance practices. Such analysis should be viewed as an important tool in the process of developing an effective corporate governance framework. To this end, effective and continuous consultation with the public is an essential element that is widely regarded as good practice. Moreover, in developing a corporate governance framework in each jurisdiction, national legislators and regulators should duly consider the need for, and the results from, effective international dialogue and cooperation. If these conditions are met, the governance system is more likely to avoid over-regulation, support the exercise of entrepreneurship and limit the risks of damaging conflicts of interest in both the private sector and in public institutions. 
A. The corporate governance framework should be developed with a view to its impact on overall economic performance, market integrity and the incentives it creates for market participants and the promotion of transparent and efficient markets.

The corporate form of organisation of economic activity is a powerful force for growth. The regulatory and legal environment within which corporations operate is therefore of key importance to overall economic outcomes. Policy makers have a responsibility to put in place a framework that is flexible enough to meet the needs of corporations operating in widely different circumstances, facilitating their development of new opportunities to create value and to determine the most efficient deployment of resources. To achieve this goal, policy makers should remain focussed on ultimate economic outcomes and when considering policy options, they will need to undertake an analysis of the impact on key variables that affect the functioning of markets, such as incentive structures, the efficiency of self-regulatory systems and dealing with systemic conflicts of interest. Transparent and efficient markets serve to discipline market participants and to promote accountability.

B. The legal and regulatory requirements that affect corporate governance practices in a jurisdiction should be consistent with the rule of law, transparent and enforceable.

If new laws and regulations are needed, such as to deal with clear cases of market imperfections, they should be designed in a way that makes them possible to implement and enforce in an efficient and even handed manner covering all parties. Consultation by government and other regulatory authorities with corporations, their representative organisations and other stakeholders, is an effective way of doing this. Mechanisms should also be established for parties to protect their rights. In order to avoid over-regulation, unenforceable laws, and unintended consequences that may impede or distort business dynamics, policy measures should be designed with a view to their overall costs and benefits. Such assessments should take into account the need for effective enforcement, including the ability of authorities to deter dishonest behaviour and to impose effective sanctions for violations.

Corporate governance objectives are also formulated in voluntary codes and standards that do not have the status of law or regulation. While such codes play an important role in improving corporate governance arrangements, they might leave shareholders and other stakeholders with uncertainty concerning their status and implementation. When codes and principles are used as a national standard or as an explicit substitute for legal or regulatory provisions, market credibility requires that their status in terms of coverage, implementation, compliance and sanctions is clearly specified. 


\section{The division of responsibilities among different authorities in a jurisdiction should be clearly articulated and ensure that the public interest is served.}

Corporate governance requirements and practices are typically influenced by an array of legal domains, such as company law, securities regulation, accounting and auditing standards, insolvency law, contract law, labour law and tax law. Under these circumstances, there is a risk that the variety of legal influences may cause unintentional overlaps and even conflicts, which may frustrate the ability to pursue key corporate governance objectives. It is important that policy-makers are aware of this risk and take measures to limit it. Effective enforcement also requires that the allocation of responsibilities for supervision, implementation and enforcement among different authorities is clearly defined so that the competencies of complementary bodies and agencies are respected and used most effectively. Overlapping and perhaps contradictory regulations between national jurisdictions is also an issue that should be monitored so that no regulatory vacuum is allowed to develop (i.e. issues slipping through in which no authority has explicit responsibility) and to minimise the cost of compliance with multiple systems by corporations.

When regulatory responsibilities or oversight are delegated to non-public bodies, it is desirable to explicitly assess why, and under what circumstances, such delegation is desirable. It is also essential that the governance structure of any such delegated institution be transparent and encompass the public interest.

D. Supervisory, regulatory and enforcement authorities should have the authority, integrity and resources to fulfil their duties in a professional and objective manner. Moreover, their rulings should be timely, transparent and fully explained.

Regulatory responsibilities should be vested with bodies that can pursue their functions without conflicts of interest and that are subject to judicial review. As the number of public companies, corporate events and the volume of disclosures increase, the resources of supervisory, regulatory and enforcement authorities may come under strain. As a result, in order to follow developments, they will have a significant demand for fully qualified staff to provide effective oversight and investigative capacity which will need to be appropriately funded. The ability to attract staff on competitive terms will enhance the quality and independence of supervision and enforcement. 


\section{The Rights of Shareholders and Key Ownership Functions}

\section{The corporate governance framework should protect and facilitate the exercise of shareholders' rights.}

Equity investors have certain property rights. For example, an equity share in a publicly traded company can be bought, sold, or transferred. An equity share also entitles the investor to participate in the profits of the corporation, with liability limited to the amount of the investment. In addition, ownership of an equity share provides a right to information about the corporation and a right to influence the corporation, primarily by participation in general shareholder meetings and by voting.

As a practical matter, however, the corporation cannot be managed by shareholder referendum. The shareholding body is made up of individuals and institutions whose interests, goals, investment horizons and capabilities vary. Moreover, the corporation's management must be able to take business decisions rapidly. In light of these realities and the complexity of managing the corporation's affairs in fast moving and ever changing markets, shareholders are not expected to assume responsibility for managing corporate activities. The responsibility for corporate strategy and operations is typically placed in the hands of the board and a management team that is selected, motivated and, when necessary, replaced by the board.

Shareholders' rights to influence the corporation centre on certain fundamental issues, such as the election of board members, or other means of influencing the composition of the board, amendments to the company's organic documents, approval of extraordinary transactions, and other basic issues as specified in company law and internal company statutes. This Section can be seen as a statement of the most basic rights of shareholders, which are recognised by law in virtually all OECD countries. Additional rights such as the approval or election of auditors, direct nomination of board members, the ability to pledge shares, the approval of distributions of profits, etc., can be found in various jurisdictions. 
A. Basic shareholder rights should include the right to: 1) secure methods of ownership registration; 2) convey or transfer shares; 3) obtain relevant and material information on the corporation on a timely and regular basis; 4) participate and vote in general shareholder meetings; 5) elect and remove members of the board; and 6) share in the profits of the corporation.

B. Shareholders should have the right to participate in, and to be sufficiently informed on, decisions concerning fundamental corporate changes such as: 1) amendments to the statutes, or articles of incorporation or similar governing documents of the company; 2) the authorisation of additional shares; and 3) extraordinary transactions, including the transfer of all or substantially all assets, that in effect result in the sale of the company.

The ability of companies to form partnerships and related companies and to transfer operational assets, cash flow rights and other rights and obligations to them is important for business flexibility and for delegating accountability in complex organisations. It also allows a company to divest itself of operational assets and to become only a holding company. However, without appropriate checks and balances such possibilities may also be abused.

C. Shareholders should have the opportunity to participate effectively and vote in general shareholder meetings and should be informed of the rules, including voting procedures, that govern general shareholder meetings:

1. Shareholders should be furnished with sufficient and timely information concerning the date, location and agenda of general meetings, as well as full and timely information regarding the issues to be decided at the meeting.

2. Shareholders should have the opportunity to ask questions to the board, including questions relating to the annual external audit, to place items on the agenda of general meetings, and to propose resolutions, subject to reasonable limitations.

In order to encourage shareholder participation in general meetings, some companies have improved the ability of shareholders to place items on the agenda by simplifying the process of filing amendments and resolutions. Improvements have also been made in order to make it easier for shareholders to submit questions in advance of the general meeting and to obtain replies from management and board members. Shareholders should also be able to ask questions relating to the external audit report. Companies are justified in assuring that abuses of such opportunities do not occur. It is reasonable, for example, to require that in order for shareholder resolutions to be placed on the agenda, they need to be supported by shareholders holding a specified market value or percentage of shares or voting rights. 
This threshold should be determined taking into account the degree of ownership concentration, in order to ensure that minority shareholders are not effectively prevented from putting any items on the agenda. Shareholder resolutions that are approved and fall within the competence of the shareholders' meeting should be addressed by the board.

3. Effective shareholder participation in key corporate governance decisions, such as the nomination and election of board members, should be facilitated. Shareholders should be able to make their views known on the remuneration policy for board members and key executives. The equity component of compensation schemes for board members and employees should be subject to shareholder approval.

To elect the members of the board is a basic shareholder right. For the election process to be effective, shareholders should be able to participate in the nomination of board members and vote on individual nominees or on different lists of them. To this end, shareholders have access in a number of countries to the company's proxy materials which are sent to shareholders, although sometimes subject to conditions to prevent abuse. With respect to nomination of candidates, boards in many companies have established nomination committees to ensure proper compliance with established nomination procedures and to facilitate and coordinate the search for a balanced and qualified board. It is increasingly regarded as good practice in many countries for independent board members to have a key role on this committee. To further improve the selection process, the Principles also call for full disclosure of the experience and background of candidates for the board and the nomination process, which will allow an informed assessment of the abilities and suitability of each candidate.

The Principles call for the disclosure of remuneration policy by the board. In particular, it is important for shareholders to know the specific link between remuneration and company performance when they assess the capability of the board and the qualities they should seek in nominees for the board. Although board and executive contracts are not an appropriate subject for approval by the general meeting of shareholders, there should be a means by which they can express their views. Several countries have introduced an advisory vote which conveys the strength and tone of shareholder sentiment to the board without endangering employment contracts. In the case of equity-based schemes, their potential to dilute shareholders' capital and to powerfully determine managerial incentives means that they should be approved by shareholders, either for individuals or for the policy of the scheme as a whole. In an increasing number of jurisdictions, any material changes to existing schemes must also be approved. 


\section{Shareholders should be able to vote in person or in absentia, and equal effect should be given to votes whether cast in person or in absentia.}

The Principles recommend that voting by proxy be generally accepted. Indeed, it is important to the promotion and protection of shareholder rights that investors can place reliance upon directed proxy voting. The corporate governance framework should ensure that proxies are voted in accordance with the direction of the proxy holder and that disclosure is provided in relation to how undirected proxies will be voted. In those jurisdictions where companies are allowed to obtain proxies, it is important to disclose how the Chairperson of the meeting (as the usual recipient of shareholder proxies obtained by the company) will exercise the voting rights attaching to undirected proxies. Where proxies are held by the board or management for company pension funds and for employee stock ownership plans, the directions for voting should be disclosed.

The objective of facilitating shareholder participation suggests that companies consider favourably the enlarged use of information technology in voting, including secure electronic voting in absentia.

D. Capital structures and arrangements that enable certain shareholders to obtain a degree of control disproportionate to their equity ownership should be disclosed.

Some capital structures allow a shareholder to exercise a degree of control over the corporation disproportionate to the shareholders' equity ownership in the company. Pyramid structures, cross shareholdings and shares with limited or multiple voting rights can be used to diminish the capability of noncontrolling shareholders to influence corporate policy.

In addition to ownership relations, other devices can affect control over the corporation. Shareholder agreements are a common means for groups of shareholders, who individually may hold relatively small shares of total equity, to act in concert so as to constitute an effective majority, or at least the largest single block of shareholders. Shareholder agreements usually give those participating in the agreements preferential rights to purchase shares if other parties to the agreement wish to sell. These agreements can also contain provisions that require those accepting the agreement not to sell their shares for a specified time. Shareholder agreements can cover issues such as how the board or the Chairman will be selected. The agreements can also oblige those in the agreement to vote as a block. Some countries have found it necessary to closely monitor such agreements and to limit their duration. 
Voting caps limit the number of votes that a shareholder may cast, regardless of the number of shares the shareholder may actually possess. Voting caps therefore redistribute control and may affect the incentives for shareholder participation in shareholder meetings.

Given the capacity of these mechanisms to redistribute the influence of shareholders on company policy, shareholders can reasonably expect that all such capital structures and arrangements be disclosed.

E. Markets for corporate control should be allowed to function in an efficient and transparent manner.

1. The rules and procedures governing the acquisition of corporate control in the capital markets, and extraordinary transactions such as mergers, and sales of substantial portions of corporate assets, should be clearly articulated and disclosed so that investors understand their rights and recourse. Transactions should occur at transparent prices and under fair conditions that protect the rights of all shareholders according to their class.

2. Anti-take-over devices should not be used to shield management and the board from accountability.

In some countries, companies employ anti-take-over devices. However, both investors and stock exchanges have expressed concern over the possibility that widespread use of anti-take-over devices may be a serious impediment to the functioning of the market for corporate control. In some instances, take-over defences can simply be devices to shield the management or the board from shareholder monitoring. In implementing any anti-takeover devices and in dealing with take-over proposals, the fiduciary duty of the board to shareholders and the company must remain paramount.

F. The exercise of ownership rights by all shareholders, including institutional investors, should be facilitated.

As investors may pursue different investment objectives, the Principles do not advocate any particular investment strategy and do not seek to prescribe the optimal degree of investor activism. Nevertheless, in considering the costs and benefits of exercising their ownership rights, many investors are likely to conclude that positive financial returns and growth can be obtained by undertaking a reasonable amount of analysis and by using their rights. 


\section{Institutional investors acting in a fiduciary capacity should disclose their overall corporate governance and voting policies with respect to their investments, including the procedures that they have in place for deciding on the use of their voting rights.}

It is increasingly common for shares to be held by institutional investors. The effectiveness and credibility of the entire corporate governance system and company oversight will, therefore, to a large extent depend on institutional investors that can make informed use of their shareholder rights and effectively exercise their ownership functions in companies in which they invest. While this principle does not require institutional investors to vote their shares, it calls for disclosure of how they exercise their ownership rights with due consideration to cost effectiveness. For institutions acting in a fiduciary capacity, such as pension funds, collective investment schemes and some activities of insurance companies, the right to vote can be considered part of the value of the investment being undertaken on behalf of their clients. Failure to exercise the ownership rights could result in a loss to the investor who should therefore be made aware of the policy to be followed by the institutional investors.

In some countries, the demand for disclosure of corporate governance policies to the market is quite detailed and includes requirements for explicit strategies regarding the circumstances in which the institution will intervene in a company; the approach they will use for such intervention; and how they will assess the effectiveness of the strategy. In several countries institutional investors are either required to disclose their actual voting records or it is regarded as good practice and implemented on an "apply or explain" basis. Disclosure is either to their clients (only with respect to the securities of each client) or, in the case of investment advisors to registered investment companies, to the market, which is a less costly procedure. A complementary approach to participation in shareholders' meetings is to establish a continuing dialogue with portfolio companies. Such a dialogue between institutional investors and companies should be encouraged, especially by lifting unnecessary regulatory barriers, although it is incumbent on the company to treat all investors equally and not to divulge information to the institutional investors which is not at the same time made available to the market. The additional information provided by a company would normally therefore include general background information about the markets in which the company is operating and further elaboration of information already available to the market. 
When fiduciary institutional investors have developed and disclosed a corporate governance policy, effective implementation requires that they also set aside the appropriate human and financial resources to pursue this policy in a way that their beneficiaries and portfolio companies can expect.

\section{Institutional investors acting in a fiduciary capacity should disclose how they manage material conflicts of interest that may affect the exercise of key ownership rights regarding their investments.}

The incentives for intermediary owners to vote their shares and exercise key ownership functions may, under certain circumstances, differ from those of direct owners. Such differences may sometimes be commercially sound but may also arise from conflicts of interest which are particularly acute when the fiduciary institution is a subsidiary or an affiliate of another financial institution, and especially an integrated financial group. When such conflicts arise from material business relationships, for example, through an agreement to manage the portfolio company's funds, such conflicts should be identified and disclosed.

At the same time, institutions should disclose what actions they are taking to minimise the potentially negative impact on their ability to exercise key ownership rights. Such actions may include the separation of bonuses for fund management from those related to the acquisition of new business elsewhere in the organisation.

G. Shareholders, including institutional shareholders, should be allowed to consult with each other on issues concerning their basic shareholder rights as defined in the Principles, subject to exceptions to prevent abuse.

It has long been recognised that in companies with dispersed ownership, individual shareholders might have too small a stake in the company to warrant the cost of taking action or for making an investment in monitoring performance. Moreover, if small shareholders did invest resources in such activities, others would also gain without having contributed (i.e. they are "free riders"). This effect, which serves to lower incentives for monitoring, is probably less of a problem for institutions, particularly financial institutions acting in a fiduciary capacity, in deciding whether to increase their ownership to a significant stake in individual companies, or to rather simply diversify. However, other costs with regard to holding a significant stake might still be high. In many instances institutional investors are prevented from doing this because it is beyond their capacity or would require investing more of their assets in one company than may be prudent. To overcome this asymmetry which favours diversification, they should be allowed, and even encouraged, to co-operate and co-ordinate their actions in nominating and electing board 
members, placing proposals on the agenda and holding discussions directly with a company in order to improve its corporate governance. More generally, shareholders should be allowed to communicate with each other without having to comply with the formalities of proxy solicitation.

It must be recognised, however, that co-operation among investors could also be used to manipulate markets and to obtain control over a company without being subject to any takeover regulations. Moreover, co-operation might also be for the purposes of circumventing competition law. For this reason, in some countries, the ability of institutional investors to co-operate on their voting strategy is either limited or prohibited. Shareholder agreements may also be closely monitored. However, if co-operation does not involve issues of corporate control, or conflict with concerns about market efficiency and fairness, the benefits of more effective ownership may still be obtained. Necessary disclosure of co-operation among investors, institutional or otherwise, may have to be accompanied by provisions which prevent trading for a period so as to avoid the possibility of market manipulation. 


\section{The Equitable Treatment of Shareholders}

\section{The corporate governance framework should ensure the equitable treatment of all shareholders, including minority and foreign shareholders. All shareholders should have the opportunity to obtain effective redress for violation of their rights.}

Investors' confidence that the capital they provide will be protected from misuse or misappropriation by corporate managers, board members or controlling shareholders is an important factor in the capital markets. Corporate boards, managers and controlling shareholders may have the opportunity to engage in activities that may advance their own interests at the expense of non-controlling shareholders. In providing protection to investors, a distinction can usefully be made between ex-ante and ex-post shareholder rights. Ex-ante rights are, for example, pre-emptive rights and qualified majorities for certain decisions. Ex-post rights allow the seeking of redress once rights have been violated. In jurisdictions where the enforcement of the legal and regulatory framework is weak, some countries have found it desirable to strengthen the ex-ante rights of shareholders such as by low share ownership thresholds for placing items on the agenda of the shareholders meeting or by requiring a supermajority of shareholders for certain important decisions. The Principles support equal treatment for foreign and domestic shareholders in corporate governance. They do not address government policies to regulate foreign direct investment.

One of the ways in which shareholders can enforce their rights is to be able to initiate legal and administrative proceedings against management and board members. Experience has shown that an important determinant of the degree to which shareholder rights are protected is whether effective methods exist to obtain redress for grievances at a reasonable cost and without excessive delay. The confidence of minority investors is enhanced when the legal system provides mechanisms for minority shareholders to bring lawsuits when they have reasonable grounds to believe that their rights have been violated. The provision of such enforcement mechanisms is a key responsibility of legislators and regulators.

There is some risk that a legal system, which enables any investor to challenge corporate activity in the courts, can become prone to excessive litigation. Thus, many legal systems have introduced provisions to protect management and board members against litigation abuse in the form of tests 
for the sufficiency of shareholder complaints, so-called safe harbours for management and board member actions (such as the business judgement rule) as well as safe harbours for the disclosure of information. In the end, a balance must be struck between allowing investors to seek remedies for infringement of ownership rights and avoiding excessive litigation. Many countries have found that alternative adjudication procedures, such as administrative hearings or arbitration procedures organised by the securities regulators or other regulatory bodies, are an efficient method for dispute settlement, at least at the first instance level.

A. All shareholders of the same series of a class should be treated equally.

1. Within any series of a class, all shares should carry the same rights. All investors should be able to obtain information about the rights attached to all series and classes of shares before they purchase. Any changes in voting rights should be subject to approval by those classes of shares which are negatively affected.

The optimal capital structure of the firm is best decided by the management and the board, subject to the approval of the shareholders. Some companies issue preferred (or preference) shares which have a preference in respect of receipt of the profits of the firm but which normally have no voting rights. Companies may also issue participation certificates or shares without voting rights, which would presumably trade at different prices than shares with voting rights. All of these structures may be effective in distributing risk and reward in ways that are thought to be in the best interests of the company and to cost-efficient financing. The Principles do not take a position on the concept of "one share one vote". However, many institutional investors and shareholder associations support this concept.

Investors can expect to be informed regarding their voting rights before they invest. Once they have invested, their rights should not be changed unless those holding voting shares have had the opportunity to participate in the decision. Proposals to change the voting rights of different series and classes of shares should be submitted for approval at general shareholders meetings by a specified majority of voting shares in the affected categories.

2. Minority shareholders should be protected from abusive actions by, or in the interest of, controlling shareholders acting either directly or indirectly, and should have effective means of redress.

Many publicly traded companies have a large controlling shareholder. While the presence of a controlling shareholder can reduce the agency 
problem by closer monitoring of management, weaknesses in the legal and regulatory framework may lead to the abuse of other shareholders in the company. The potential for abuse is marked where the legal system allows, and the market accepts, controlling shareholders to exercise a level of control which does not correspond to the level of risk that they assume as owners through exploiting legal devices to separate ownership from control, such as pyramid structures or multiple voting rights. Such abuse may be carried out in various ways, including the extraction of direct private benefits via high pay and bonuses for employed family members and associates, inappropriate related party transactions, systematic bias in business decisions and changes in the capital structure through special issuance of shares favouring the controlling shareholder.

In addition to disclosure, a key to protecting minority shareholders is a clearly articulated duty of loyalty by board members to the company and to all shareholders. Indeed, abuse of minority shareholders is most pronounced in those countries where the legal and regulatory framework is weak in this regard. A particular issue arises in some jurisdictions where groups of companies are prevalent and where the duty of loyalty of a board member might be ambiguous and even interpreted as to the group. In these cases, some countries are now moving to control negative effects by specifying that a transaction in favour of another group company must be offset by receiving a corresponding benefit from other companies of the group.

Other common provisions to protect minority shareholders, which have proven effective, include pre-emptive rights in relation to share issues, qualified majorities for certain shareholder decisions and the possibility to use cumulative voting in electing members of the board. Under certain circumstances, some jurisdictions require or permit controlling shareholders to buy-out the remaining shareholders at a share-price that is established through an independent appraisal. This is particularly important when controlling shareholders decide to de-list an enterprise. Other means of improving minority shareholder rights include derivative and class action law suits. With the common aim of improving market credibility, the choice and ultimate design of different provisions to protect minority shareholders necessarily depends on the overall regulatory framework and the national legal system.

\section{Votes should be cast by custodians or nominees in a manner agreed upon with the beneficial owner of the shares.}

In some OECD countries it was customary for financial institutions which held shares in custody for investors to cast the votes of those shares. Custodians such as banks and brokerage firms holding securities as 
nominees for customers were sometimes required to vote in support of management unless specifically instructed by the shareholder to do otherwise.

The trend in OECD countries is to remove provisions that automatically enable custodian institutions to cast the votes of shareholders. Rules in some countries have recently been revised to require custodian institutions to provide shareholders with information concerning their options in the use of their voting rights. Shareholders may elect to delegate all voting rights to custodians. Alternatively, shareholders may choose to be informed of all upcoming shareholder votes and may decide to cast some votes while delegating some voting rights to the custodian. It is necessary to draw a reasonable balance between assuring that shareholder votes are not cast by custodians without regard for the wishes of shareholders and not imposing excessive burdens on custodians to secure shareholder approval before casting votes. It is sufficient to disclose to the shareholders that, if no instruction to the contrary is received, the custodian will vote the shares in the way it deems consistent with shareholder interest.

It should be noted that this principle does not apply to the exercise of voting rights by trustees or other persons acting under a special legal mandate (such as, for example, bankruptcy receivers and estate executors).

Holders of depository receipts should be provided with the same ultimate rights and practical opportunities to participate in corporate governance as are accorded to holders of the underlying shares. Where the direct holders of shares may use proxies, the depositary, trust office or equivalent body should therefore issue proxies on a timely basis to depository receipt holders. The depository receipt holders should be able to issue binding voting instructions with respect to the shares, which the depositary or trust office holds on their behalf.

\section{Impediments to cross border voting should be eliminated.}

Foreign investors often hold their shares through chains of intermediaries. Shares are typically held in accounts with securities intermediaries, that in turn hold accounts with other intermediaries and central securities depositories in other jurisdictions, while the listed company resides in a third country. Such cross-border chains cause special challenges with respect to determining the entitlement of foreign investors to use their voting rights, and the process of communicating with such investors. In combination with business practices which provide only a very short notice period, shareholders are often left with only very limited time to 
react to a convening notice by the company and to make informed decisions concerning items for decision. This makes cross border voting difficult. The legal and regulatory framework should clarify who is entitled to control the voting rights in cross border situations and where necessary to simplify the depository chain. Moreover, notice periods should ensure that foreign investors in effect have similar opportunities to exercise their ownership functions as domestic investors. To further facilitate voting by foreign investors, laws, regulations and corporate practices should allow participation through means which make use of modern technology.

\section{Processes and procedures for general shareholder meetings should allow for equitable treatment of all shareholders. Company procedures should not make it unduly difficult or expensive to cast votes.}

The right to participate in general shareholder meetings is a fundamental shareholder right. Management and controlling investors have at times sought to discourage non-controlling or foreign investors from trying to influence the direction of the company. Some companies have charged fees for voting. Other impediments included prohibitions on proxy voting and the requirement of personal attendance at general shareholder meetings to vote. Still other procedures may make it practically impossible to exercise ownership rights. Proxy materials may be sent too close to the time of general shareholder meetings to allow investors adequate time for reflection and consultation. Many companies in OECD countries are seeking to develop better channels of communication and decision-making with shareholders. Efforts by companies to remove artificial barriers to participation in general meetings are encouraged and the corporate governance framework should facilitate the use of electronic voting in absentia.

\section{B. Insider trading and abusive self-dealing should be prohibited.}

Abusive self-dealing occurs when persons having close relationships to the company, including controlling shareholders, exploit those relationships to the detriment of the company and investors. As insider trading entails manipulation of the capital markets, it is prohibited by securities regulations, company law and/or criminal law in most OECD countries. However, not all jurisdictions prohibit such practices, and in some cases enforcement is not vigorous. These practices can be seen as constituting a breach of good corporate governance inasmuch as they violate the principle of equitable treatment of shareholders.

The Principles reaffirm that it is reasonable for investors to expect that the abuse of insider power be prohibited. In cases where such abuses are not 
specifically forbidden by legislation or where enforcement is not effective, it will be important for governments to take measures to remove any such gaps.

C. Members of the board and key executives should be required to disclose to the board whether they, directly, indirectly or on behalf of third parties, have a material interest in any transaction or matter directly affecting the corporation.

Members of the board and key executives have an obligation to inform the board where they have a business, family or other special relationship outside of the company that could affect their judgement with respect to a particular transaction or matter affecting the company. Such special relationships include situations where executives and board members have a relationship with the company via their association with a shareholder who is in a position to exercise control. Where a material interest has been declared, it is good practice for that person not to be involved in any decision involving the transaction or matter. 


\section{The Role of Stakeholders in Corporate Governance}

The corporate governance framework should recognise the rights of stakeholders established by law or through mutual agreements and encourage active co-operation between corporations and stakeholders in creating wealth, jobs, and the sustainability of financially sound enterprises.

A key aspect of corporate governance is concerned with ensuring the flow of external capital to companies both in the form of equity and credit. Corporate governance is also concerned with finding ways to encourage the various stakeholders in the firm to undertake economically optimal levels of investment in firm-specific human and physical capital. The competitiveness and ultimate success of a corporation is the result of teamwork that embodies contributions from a range of different resource providers including investors, employees, creditors, and suppliers. Corporations should recognise that the contributions of stakeholders constitute a valuable resource for building competitive and profitable companies. It is, therefore, in the long-term interest of corporations to foster wealth-creating cooperation among stakeholders. The governance framework should recognise that the interests of the corporation are served by recognising the interests of stakeholders and their contribution to the long-term success of the corporation.

A. The rights of stakeholders that are established by law or through mutual agreements are to be respected.

In all OECD countries, the rights of stakeholders are established by law (e.g. labour, business, commercial and insolvency laws) or by contractual relations. Even in areas where stakeholder interests are not legislated, many firms make additional commitments to stakeholders, and concern over corporate reputation and corporate performance often requires the recognition of broader interests.

B. Where stakeholder interests are protected by law, stakeholders should have the opportunity to obtain effective redress for violation of their rights.

The legal framework and process should be transparent and not impede the ability of stakeholders to communicate and to obtain redress for the violation of rights. 


\section{Performance-enhancing mechanisms for employee participation should be permitted to develop.}

The degree to which employees participate in corporate governance depends on national laws and practices, and may vary from company to company as well. In the context of corporate governance, performance enhancing mechanisms for participation may benefit companies directly as well as indirectly through the readiness by employees to invest in firm specific skills. Examples of mechanisms for employee participation include: employee representation on boards; and governance processes such as works councils that consider employee viewpoints in certain key decisions. With respect to performance enhancing mechanisms, employee stock ownership plans or other profit sharing mechanisms are to be found in many countries. Pension commitments are also often an element of the relationship between the company and its past and present employees. Where such commitments involve establishing an independent fund, its trustees should be independent of the company's management and manage the fund for all beneficiaries.

D. Where stakeholders participate in the corporate governance process, they should have access to relevant, sufficient and reliable information on a timely and regular basis.

Where laws and practice of corporate governance systems provide for participation by stakeholders, it is important that stakeholders have access to information necessary to fulfil their responsibilities.

E. Stakeholders, including individual employees and their representative bodies, should be able to freely communicate their concerns about illegal or unethical practices to the board and their rights should not be compromised for doing this.

Unethical and illegal practices by corporate officers may not only violate the rights of stakeholders but also be to the detriment of the company and its shareholders in terms of reputation effects and an increasing risk of future financial liabilities. It is therefore to the advantage of the company and its shareholders to establish procedures and safe-harbours for complaints by employees, either personally or through their representative bodies, and others outside the company, concerning illegal and unethical behaviour. In many countries the board is being encouraged by laws and or principles to protect these individuals and representative bodies and to give them confidential direct access to someone independent on the board, often a member of an audit or an ethics committee. Some companies have established an ombudsman to deal with complaints. Several regulators have also established confidential phone and e-mail facilities to receive allegations. While in certain 
countries representative employee bodies undertake the tasks of conveying concerns to the company, individual employees should not be precluded from, or be less protected, when acting alone. When there is an inadequate response to a complaint regarding contravention of the law, the OECD Guidelines for Multinational Enterprises encourage them to report their bona fide complaint to the competent public authorities. The company should refrain from discriminatory or disciplinary actions against such employees or bodies.

F. The corporate governance framework should be complemented by an effective, efficient insolvency framework and by effective enforcement of creditor rights.

Especially in emerging markets, creditors are a key stakeholder and the terms, volume and type of credit extended to firms will depend importantly on their rights and on their enforceability. Companies with a good corporate governance record are often able to borrow larger sums and on more favourable terms than those with poor records or which operate in nontransparent markets. The framework for corporate insolvency varies widely across countries. In some countries, when companies are nearing insolvency, the legislative framework imposes a duty on directors to act in the interests of creditors, who might therefore play a prominent role in the governance of the company. Other countries have mechanisms which encourage the debtor to reveal timely information about the company's difficulties so that a consensual solution can be found between the debtor and its creditors.

Creditor rights vary, ranging from secured bond holders to unsecured creditors. Insolvency procedures usually require efficient mechanisms for reconciling the interests of different classes of creditors. In many jurisdictions provision is made for special rights such as through "debtor in possession" financing which provides incentives/protection for new funds made available to the enterprise in bankruptcy. 


\section{Disclosure and Transparency}

The corporate governance framework should ensure that timely and accurate disclosure is made on all material matters regarding the corporation, including the financial situation, performance, ownership, and governance of the company.

In most OECD countries a large amount of information, both mandatory and voluntary, is compiled on publicly traded and large unlisted enterprises, and subsequently disseminated to a broad range of users. Public disclosure is typically required, at a minimum, on an annual basis though some countries require periodic disclosure on a semi-annual or quarterly basis, or even more frequently in the case of material developments affecting the company. Companies often make voluntary disclosure that goes beyond minimum disclosure requirements in response to market demand.

A strong disclosure regime that promotes real transparency is a pivotal feature of market-based monitoring of companies and is central to shareholders' ability to exercise their ownership rights on an informed basis. Experience in countries with large and active equity markets shows that disclosure can also be a powerful tool for influencing the behaviour of companies and for protecting investors. A strong disclosure regime can help to attract capital and maintain confidence in the capital markets. By contrast, weak disclosure and non-transparent practices can contribute to unethical behaviour and to a loss of market integrity at great cost, not just to the company and its shareholders but also to the economy as a whole. Shareholders and potential investors require access to regular, reliable and comparable information in sufficient detail for them to assess the stewardship of management, and make informed decisions about the valuation, ownership and voting of shares. Insufficient or unclear information may hamper the ability of the markets to function, increase the cost of capital and result in a poor allocation of resources.

Disclosure also helps improve public understanding of the structure and activities of enterprises, corporate policies and performance with respect to environmental and ethical standards, and companies' relationships with the communities in which they operate. The OECD Guidelines for Multinational Enterprises are relevant in this context.

Disclosure requirements are not expected to place unreasonable administrative or cost burdens on enterprises. Nor are companies expected 
to disclose information that may endanger their competitive position unless disclosure is necessary to fully inform the investment decision and to avoid misleading the investor. In order to determine what information should be disclosed at a minimum, many countries apply the concept of materiality. Material information can be defined as information whose omission or misstatement could influence the economic decisions taken by users of information.

The Principles support timely disclosure of all material developments that arise between regular reports. They also support simultaneous reporting of information to all shareholders in order to ensure their equitable treatment. In maintaining close relations with investors and market participants, companies must be careful not to violate this fundamental principle of equitable treatment.

\section{A. Disclosure should include, but not be limited to, material information on:}

\section{The financial and operating results of the company.}

Audited financial statements showing the financial performance and the financial situation of the company (most typically including the balance sheet, the profit and loss statement, the cash flow statement and notes to the financial statements) are the most widely used source of information on companies. In their current form, the two principal goals of financial statements are to enable appropriate monitoring to take place and to provide the basis to value securities. Management's discussion and analysis of operations is typically included in annual reports. This discussion is most useful when read in conjunction with the accompanying financial statements. Investors are particularly interested in information that may shed light on the future performance of the enterprise.

Arguably, failures of governance can often be linked to the failure to disclose the "whole picture", particularly where off-balance sheet items are used to provide guarantees or similar commitments between related companies. It is therefore important that transactions relating to an entire group of companies be disclosed in line with high quality internationally recognised standards and include information about contingent liabilities and off-balance sheet transactions, as well as special purpose entities.

\section{Company objectives.}

In addition to their commercial objectives, companies are encouraged to disclose policies relating to business ethics, the environment and other public policy commitments. Such information may be important for 
investors and other users of information to better evaluate the relationship between companies and the communities in which they operate and the steps that companies have taken to implement their objectives.

\section{Major share ownership and voting rights.}

One of the basic rights of investors is to be informed about the ownership structure of the enterprise and their rights vis-à-vis the rights of other owners. The right to such information should also extend to information about the structure of a group of companies and intra-group relations. Such disclosures should make transparent the objectives, nature and structure of the group. Countries often require disclosure of ownership data once certain thresholds of ownership are passed. Such disclosure might include data on major shareholders and others that, directly or indirectly, control or may control the company through special voting rights, shareholder agreements, the ownership of controlling or large blocks of shares, significant cross shareholding relationships and cross guarantees.

Particularly for enforcement purposes, and to identify potential conflicts of interest, related party transactions and insider trading, information about record ownership may have to be complemented with information about beneficial ownership. In cases where major shareholdings are held through intermediary structures or arrangements, information about the beneficial owners should therefore be obtainable at least by regulatory and enforcement agencies and/or through the judicial process. The OECD template Options for Obtaining Beneficial Ownership and Control Information can serve as a useful self-assessment tool for countries that wish to ensure necessary access to information about beneficial ownership.

4. Remuneration policy for members of the board and key executives, and information about board members, including their qualifications, the selection process, other company directorships and whether they are regarded as independent by the board.

Investors require information on individual board members and key executives in order to evaluate their experience and qualifications and assess any potential conflicts of interest that might affect their judgement. For board members, the information should include their qualifications, share ownership in the company, membership of other boards and whether they are considered by the board to be an independent member. It is important to disclose membership of other boards not only because it is an indication of experience and possible time pressures facing a member 
of the board, but also because it may reveal potential conflicts of interest and makes transparent the degree to which there are inter-locking boards.

A number of national principles, and in some cases laws, lay down specific duties for board members who can be regarded as independent and in some instances recommend that a majority of the board should be independent. In many countries, it is incumbent on the board to set out the reasons why a member of the board can be considered independent. It is then up to the shareholders, and ultimately the market, to determine if those reasons are justified. Several countries have concluded that companies should disclose the selection process and especially whether it was open to a broad field of candidates. Such information should be provided in advance of any decision by the general shareholder's meeting or on a continuing basis if the situation has changed materially.

Information about board and executive remuneration is also of concern to shareholders. Of particular interest is the link between remuneration and company performance. Companies are generally expected to disclose information on the remuneration of board members and key executives so that investors can assess the costs and benefits of remuneration plans and the contribution of incentive schemes, such as stock option schemes, to company performance. Disclosure on an individual basis (including termination and retirement provisions) is increasingly regarded as good practice and is now mandated in several countries. In these cases, some jurisdictions call for remuneration of a certain number of the highest paid executives to be disclosed, while in others it is confined to specified positions.

\section{Related party transactions.}

It is important for the market to know whether the company is being run with due regard to the interests of all its investors. To this end, it is essential for the company to fully disclose material related party transactions to the market, either individually, or on a grouped basis, including whether they have been executed at arms-length and on normal market terms. In a number of jurisdictions this is indeed already a legal requirement. Related parties can include entities that control or are under common control with the company, significant shareholders including members of their families and key management personnel.

Transactions involving the major shareholders (or their close family, relations etc.), either directly or indirectly, are potentially the most difficult type of transactions. In some jurisdictions, shareholders above a limit as low as 5 per cent shareholding are obliged to report transactions. Disclosure requirements include the nature of the relationship where 
control exists and the nature and amount of transactions with related parties, grouped as appropriate. Given the inherent opaqueness of many transactions, the obligation may need to be placed on the beneficiary to inform the board about the transaction, which in turn should make a disclosure to the market. This should not absolve the firm from maintaining its own monitoring, which is an important task for the board.

\section{Foreseeable risk factors.}

Users of financial information and market participants need information on reasonably foreseeable material risks that may include: risks that are specific to the industry or the geographical areas in which the company operates; dependence on commodities; financial market risks including interest rate or currency risk; risk related to derivatives and off-balance sheet transactions; and risks related to environmental liabilities.

The Principles do not envision the disclosure of information in greater detail than is necessary to fully inform investors of the material and foreseeable risks of the enterprise. Disclosure of risk is most effective when it is tailored to the particular industry in question. Disclosure about the system for monitoring and managing risk is increasingly regarded as good practice.

\section{Issues regarding employees and other stakeholders.}

Companies are encouraged, and in some countries even obliged, to provide information on key issues relevant to employees and other stakeholders that may materially affect the performance of the company. Disclosure may include management/employee relations, and relations with other stakeholders such as creditors, suppliers, and local communities.

Some countries require extensive disclosure of information on human resources. Human resource policies, such as programmes for human resource development and training, retention rates of employees and employee share ownership plans, can communicate important information on the competitive strengths of companies to market participants.

8. Governance structures and policies, in particular, the content of any corporate governance code or policy and the process by which it is implemented.

Companies should report their corporate governance practices, and in a number of countries such disclosure is now mandated as part of the regular reporting. In several countries, companies must implement corporate governance principles set, or endorsed, by the listing authority 
with mandatory reporting on a "comply or explain" basis. Disclosure of the governance structures and policies of the company, in particular the division of authority between shareholders, management and board members is important for the assessment of a company's governance.

As a matter of transparency, procedures for shareholders meetings should ensure that votes are properly counted and recorded, and that a timely announcement of the outcome is made.

\section{B. Information should be prepared and disclosed in accordance with high quality standards of accounting and financial and non-financial disclosure.}

The application of high quality standards is expected to significantly improve the ability of investors to monitor the company by providing increased reliability and comparability of reporting, and improved insight into company performance. The quality of information substantially depends on the standards under which it is compiled and disclosed. The Principles support the development of high quality internationally recognised standards, which can serve to improve transparency and the comparability of financial statements and other financial reporting between countries. Such standards should be developed through open, independent, and public processes involving the private sector and other interested parties such as professional associations and independent experts. High quality domestic standards can be achieved by making them consistent with one of the internationally recognised accounting standards. In many countries, listed companies are required to use these standards.

C. An annual audit should be conducted by an independent, competent and qualified, auditor in order to provide an external and objective assurance to the board and shareholders that the financial statements fairly represent the financial position and performance of the company in all material respects.

In addition to certifying that the financial statements represent fairly the financial position of a company, the audit statement should also include an opinion on the way in which financial statements have been prepared and presented. This should contribute to an improved control environment in the company.

Many countries have introduced measures to improve the independence of auditors and to tighten their accountability to shareholders. A number of countries are tightening audit oversight through an independent entity. Indeed, the Principles of Auditor Oversight issued by IOSCO in 2002 states that effective auditor oversight generally includes, inter alia, mechanisms: “...to provide that a body, acting in the public interest, provides oversight over the quality and implementation, and ethical standards used in the jurisdiction, as 
well as audit quality control environments"; and "...to require auditors to be subject to the discipline of an auditor oversight body that is independent of the audit profession, or, if a professional body acts as the oversight body, is overseen by an independent body". It is desirable for such an auditor oversight body to operate in the public interest, and have an appropriate membership, an adequate charter of responsibilities and powers, and adequate funding that is not under the control of the auditing profession, to carry out those responsibilities.

It is increasingly common for external auditors to be recommended by an independent audit committee of the board or an equivalent body and to be appointed either by that committee/body or by shareholders directly. Moreover, the IOSCO Principles of Auditor Independence and the Role of Corporate Governance in Monitoring an Auditor's Independence states that, "standards of auditor independence should establish a framework of principles, supported by a combination of prohibitions, restrictions, other policies and procedures and disclosures, that addresses at least the following threats to independence: self-interest, self-review, advocacy, familiarity and intimidation".

The audit committee or an equivalent body is often specified as providing oversight of the internal audit activities and should also be charged with overseeing the overall relationship with the external auditor including the nature of non-audit services provided by the auditor to the company. Provision of non-audit services by the external auditor to a company can significantly impair their independence and might involve them auditing their own work. To deal with the skewed incentives which may arise, a number of countries now call for disclosure of payments to external auditors for non-audit services. Examples of other provisions to underpin auditor independence include, a total ban or severe limitation on the nature of non-audit work which can be undertaken by an auditor for their audit client, mandatory rotation of auditors (either partners or in some cases the audit partnership), a temporary ban on the employment of an ex-auditor by the audited company and prohibiting auditors or their dependents from having a financial stake or management role in the companies they audit. Some countries take a more direct regulatory approach and limit the percentage of non-audit income that the auditor can receive from a particular client or limit the total percentage of auditor income that can come from one client.

An issue which has arisen in some jurisdictions concerns the pressing need to ensure the competence of the audit profession. In many cases there is a registration process for individuals to confirm their qualifications. This needs, however, to be supported by ongoing training and monitoring of work experience to ensure an appropriate level of professional competence. 
D. External auditors should be accountable to the shareholders and owe a duty to the company to exercise due professional care in the conduct of the audit.

The practice that external auditors are recommended by an independent audit committee of the board or an equivalent body and that external auditors are appointed either by that committee/body or by the shareholders' meeting directly can be regarded as good practice since it clarifies that the external auditor should be accountable to the shareholders. It also underlines that the external auditor owes a duty of due professional care to the company rather than any individual or group of corporate managers that they may interact with for the purpose of their work.

E. Channels for disseminating information should provide for equal, timely and cost-efficient access to relevant information by users.

Channels for the dissemination of information can be as important as the content of the information itself. While the disclosure of information is often provided for by legislation, filing and access to information can be cumbersome and costly. Filing of statutory reports has been greatly enhanced in some countries by electronic filing and data retrieval systems. Some countries are now moving to the next stage by integrating different sources of company information, including shareholder filings. The Internet and other information technologies also provide the opportunity for improving information dissemination.

A number of countries have introduced provisions for ongoing disclosure (often prescribed by law or by listing rules) which includes periodic disclosure and continuous or current disclosure which must be provided on an ad hoc basis. With respect to continuous/current disclosure, good practice is to call for "immediate" disclosure of material developments, whether this means "as soon as possible" or is defined as a prescribed maximum number of specified days. The IOSCO Principles for Ongoing Disclosure and Material Development Reporting by Listed Entities set forth common principles of ongoing disclosure and material development reporting for listed companies.

F. The corporate governance framework should be complemented by an effective approach that addresses and promotes the provision of analysis or advice by analysts, brokers, rating agencies and others, that is relevant to decisions by investors, free from material conflicts of interest that might compromise the integrity of their analysis or advice.

In addition to demanding independent and competent auditors, and to facilitate timely dissemination of information, a number of countries have taken steps to ensure the integrity of those professions and activities that serve as conduits of analysis and advice to the market. These intermediaries, if they 
are operating free from conflicts and with integrity, can play an important role in providing incentives for company boards to follow good corporate governance practices.

Concerns have arisen, however, in response to evidence that conflicts of interest often arise and may affect judgement. This could be the case when the provider of advice is also seeking to provide other services to the company in question, or where the provider has a direct material interest in the company or its competitors. The concern identifies a highly relevant dimension of the disclosure and transparency process that targets the professional standards of stock market research analysts, rating agencies, investment banks, etc.

Experience in other areas indicates that the preferred solution is to demand full disclosure of conflicts of interest and how the entity is choosing to manage them. Particularly important will be disclosure about how the entity is structuring the incentives of its employees in order to eliminate the potential conflict of interest. Such disclosure allows investors to judge the risks involved and the likely bias in the advice and information. IOSCO has developed statements of principles relating to analysts and rating agencies (IOSCO Statement of Principles for Addressing Sell-side Securities Analyst Conflicts of Interest; IOSCO Statement of Principles Regarding the Activities of Credit Rating Agencies). 


\section{The Responsibilities of the Board}

The corporate governance framework should ensure the strategic guidance of the company, the effective monitoring of management by the board, and the board's accountability to the company and the shareholders.

Board structures and procedures vary both within and among OECD countries. Some countries have two-tier boards that separate the supervisory function and the management function into different bodies. Such systems typically have a "supervisory board" composed of non-executive board members and a "management board" composed entirely of executives. Other countries have "unitary" boards, which bring together executive and nonexecutive board members. In some countries there is also an additional statutory body for audit purposes. The Principles are intended to be sufficiently general to apply to whatever board structure is charged with the functions of governing the enterprise and monitoring management.

Together with guiding corporate strategy, the board is chiefly responsible for monitoring managerial performance and achieving an adequate return for shareholders, while preventing conflicts of interest and balancing competing demands on the corporation. In order for boards to effectively fulfil their responsibilities they must be able to exercise objective and independent judgement. Another important board responsibility is to oversee systems designed to ensure that the corporation obeys applicable laws, including tax, competition, labour, environmental, equal opportunity, health and safety laws. In some countries, companies have found it useful to explicitly articulate the responsibilities that the board assumes and those for which management is accountable.

The board is not only accountable to the company and its shareholders but also has a duty to act in their best interests. In addition, boards are expected to take due regard of, and deal fairly with, other stakeholder interests including those of employees, creditors, customers, suppliers and local communities. Observance of environmental and social standards is relevant in this context. 


\section{A. Board members should act on a fully informed basis, in good faith, with due diligence and care, and in the best interest of the company and the shareholders.}

In some countries, the board is legally required to act in the interest of the company, taking into account the interests of shareholders, employees, and the public good. Acting in the best interest of the company should not permit management to become entrenched.

This principle states the two key elements of the fiduciary duty of board members: the duty of care and the duty of loyalty. The duty of care requires board members to act on a fully informed basis, in good faith, with due diligence and care. In some jurisdictions there is a standard of reference which is the behaviour that a reasonably prudent person would exercise in similar circumstances. In nearly all jurisdictions, the duty of care does not extend to errors of business judgement so long as board members are not grossly negligent and a decision is made with due diligence etc. The principle calls for board members to act on a fully informed basis. Good practice takes this to mean that they should be satisfied that key corporate information and compliance systems are fundamentally sound and underpin the key monitoring role of the board advocated by the Principles. In many jurisdictions this meaning is already considered an element of the duty of care, while in others it is required by securities regulation, accounting standards etc. The duty of loyalty is of central importance, since it underpins effective implementation of other principles in this document relating to, for example, the equitable treatment of shareholders, monitoring of related party transactions and the establishment of remuneration policy for key executives and board members. It is also a key principle for board members who are working within the structure of a group of companies: even though a company might be controlled by another enterprise, the duty of loyalty for a board member relates to the company and all its shareholders and not to the controlling company of the group.

B. Where board decisions may affect different shareholder groups differently, the board should treat all shareholders fairly.

In carrying out its duties, the board should not be viewed, or act, as an assembly of individual representatives for various constituencies. While specific board members may indeed be nominated or elected by certain shareholders (and sometimes contested by others) it is an important feature of the board's work that board members when they assume their responsibilities carry out their duties in an even-handed manner with respect to all shareholders. This principle is particularly important to establish in the 
presence of controlling shareholders that de facto may be able to select all board members.

C. The board should apply high ethical standards. It should take into account the interests of stakeholders.

The board has a key role in setting the ethical tone of a company, not only by its own actions, but also in appointing and overseeing key executives and consequently the management in general. High ethical standards are in the long term interests of the company as a means to make it credible and trustworthy, not only in day-to-day operations but also with respect to longer term commitments. To make the objectives of the board clear and operational, many companies have found it useful to develop company codes of conduct based on, inter alia, professional standards and sometimes broader codes of behaviour. The latter might include a voluntary commitment by the company (including its subsidiaries) to comply with the OECD Guidelines for Multinational Enterprises which reflect all four principles contained in the ILO Declaration on Fundamental Labour Rights.

Company-wide codes serve as a standard for conduct by both the board and key executives, setting the framework for the exercise of judgement in dealing with varying and often conflicting constituencies. At a minimum, the ethical code should set clear limits on the pursuit of private interests, including dealings in the shares of the company. An overall framework for ethical conduct goes beyond compliance with the law, which should always be a fundamental requirement.

D. The board should fulfil certain key functions, including:

1. Reviewing and guiding corporate strategy, major plans of action, risk policy, annual budgets and business plans; setting performance objectives; monitoring implementation and corporate performance; and overseeing major capital expenditures, acquisitions and divestitures.

An area of increasing importance for boards and which is closely related to corporate strategy is risk policy. Such policy will involve specifying the types and degree of risk that a company is willing to accept in pursuit of its goals. It is thus a crucial guideline for management that must manage risks to meet the company's desired risk profile.

2. Monitoring the effectiveness of the company's governance practices and making changes as needed.

Monitoring of governance by the board also includes continuous review of the internal structure of the company to ensure that there are clear lines 
of accountability for management throughout the organisation. In addition to requiring the monitoring and disclosure of corporate governance practices on a regular basis, a number of countries have moved to recommend or indeed mandate self-assessment by boards of their performance as well as performance reviews of individual board members and the $\mathrm{CEO} / \mathrm{Chairman}$.

3. Selecting, compensating, monitoring and, when necessary, replacing key executives and overseeing succession planning.

In two tier board systems the supervisory board is also responsible for appointing the management board which will normally comprise most of the key executives.

4. Aligning key executive and board remuneration with the longer term interests of the company and its shareholders.

In an increasing number of countries it is regarded as good practice for boards to develop and disclose a remuneration policy statement covering board members and key executives. Such policy statements specify the relationship between remuneration and performance, and include measurable standards that emphasise the longer run interests of the company over short term considerations. Policy statements generally tend to set conditions for payments to board members for extra-board activities, such as consulting. They also often specify terms to be observed by board members and key executives about holding and trading the stock of the company, and the procedures to be followed in granting and re-pricing of options. In some countries, policy also covers the payments to be made when terminating the contract of an executive.

It is considered good practice in an increasing number of countries that remuneration policy and employment contracts for board members and key executives be handled by a special committee of the board comprising either wholly or a majority of independent directors. There are also calls for a remuneration committee that excludes executives that serve on each others' remuneration committees, which could lead to conflicts of interest.

5. Ensuring a formal and transparent board nomination and election process.

These Principles promote an active role for shareholders in the nomination and election of board members. The board has an essential role to play in ensuring that this and other aspects of the nominations and election process are respected. First, while actual procedures for nomination may differ among countries, the board or a nomination 
committee has a special responsibility to make sure that established procedures are transparent and respected. Second, the board has a key role in identifying potential members for the board with the appropriate knowledge, competencies and expertise to complement the existing skills of the board and thereby improve its value-adding potential for the company. In several countries there are calls for an open search process extending to a broad range of people.

6. Monitoring and managing potential conflicts of interest of management, board members and shareholders, including misuse of corporate assets and abuse in related party transactions.

It is an important function of the board to oversee the internal control systems covering financial reporting and the use of corporate assets and to guard against abusive related party transactions. These functions are sometimes assigned to the internal auditor which should maintain direct access to the board. Where other corporate officers are responsible such as the general counsel, it is important that they maintain similar reporting responsibilities as the internal auditor.

In fulfilling its control oversight responsibilities it is important for the board to encourage the reporting of unethical/unlawful behaviour without fear of retribution. The existence of a company code of ethics should aid this process which should be underpinned by legal protection for the individuals concerned. In a number of companies either the audit committee or an ethics committee is specified as the contact point for employees who wish to report concerns about unethical or illegal behaviour that might also compromise the integrity of financial statements.

7. Ensuring the integrity of the corporation's accounting and financial reporting systems, including the independent audit, and that appropriate systems of control are in place, in particular, systems for risk management, financial and operational control, and compliance with the law and relevant standards.

Ensuring the integrity of the essential reporting and monitoring systems will require the board to set and enforce clear lines of responsibility and accountability throughout the organisation. The board will also need to ensure that there is appropriate oversight by senior management. One way of doing this is through an internal audit system directly reporting to the board. In some jurisdictions it is considered good practice for the internal auditors to report to an independent audit committee of the board or an equivalent body which is also responsible for managing the relationship with the external auditor, thereby allowing a coordinated response by the 
board. It should also be regarded as good practice for this committee, or equivalent body, to review and report to the board the most critical accounting policies which are the basis for financial reports. However, the board should retain final responsibility for ensuring the integrity of the reporting systems. Some countries have provided for the chair of the board to report on the internal control process.

Companies are also well advised to set up internal programmes and procedures to promote compliance with applicable laws, regulations and standards, including statutes to criminalise bribery of foreign officials that are required to be enacted by the OECD Anti-bribery Convention and measures designed to control other forms of bribery and corruption. Moreover, compliance must also relate to other laws and regulations such as those covering securities, competition and work and safety conditions. Such compliance programmes will also underpin the company's ethical code. To be effective, the incentive structure of the business needs to be aligned with its ethical and professional standards so that adherence to these values is rewarded and breaches of law are met with dissuasive consequences or penalties. Compliance programmes should also extend where possible to subsidiaries.

\section{Overseeing the process of disclosure and communications.}

The functions and responsibilities of the board and management with respect to disclosure and communication need to be clearly established by the board. In some companies there is now an investment relations officer who reports directly to the board.

\section{E. The board should be able to exercise objective independent judgement on corporate affairs.}

In order to exercise its duties of monitoring managerial performance, preventing conflicts of interest and balancing competing demands on the corporation, it is essential that the board is able to exercise objective judgement. In the first instance this will mean independence and objectivity with respect to management with important implications for the composition and structure of the board. Board independence in these circumstances usually requires that a sufficient number of board members will need to be independent of management. In a number of countries with single tier board systems, the objectivity of the board and its independence from management may be strengthened by the separation of the role of chief executive and chairman, or, if these roles are combined, by designating a lead non-executive director to convene or chair sessions of the outside directors. Separation of the two posts may be regarded as good practice, as it can help to achieve an appropriate balance of power, increase accountability and improve the board's capacity for 
decision making independent of management. The designation of a lead director is also regarded as a good practice alternative in some jurisdictions. Such mechanisms can also help to ensure high quality governance of the enterprise and the effective functioning of the board. The Chairman or lead director may, in some countries, be supported by a company secretary. In the case of two tier board systems, consideration should be given to whether corporate governance concerns might arise if there is a tradition for the head of the lower board becoming the Chairman of the Supervisory Board on retirement.

The manner in which board objectivity might be underpinned also depends on the ownership structure of the company. A dominant shareholder has considerable powers to appoint the board and the management. However, in this case, the board still has a fiduciary responsibility to the company and to all shareholders including minority shareholders.

The variety of board structures, ownership patterns and practices in different countries will thus require different approaches to the issue of board objectivity. In many instances objectivity requires that a sufficient number of board members not be employed by the company or its affiliates and not be closely related to the company or its management through significant economic, family or other ties. This does not prevent shareholders from being board members. In others, independence from controlling shareholders or another controlling body will need to be emphasised, in particular if the exante rights of minority shareholders are weak and opportunities to obtain redress are limited. This has led to both codes and the law in some jurisdictions to call for some board members to be independent of dominant shareholders, independence extending to not being their representative or having close business ties with them. In other cases, parties such as particular creditors can also exercise significant influence. Where there is a party in a special position to influence the company, there should be stringent tests to ensure the objective judgement of the board.

In defining independent members of the board, some national principles of corporate governance have specified quite detailed presumptions for nonindependence which are frequently reflected in listing requirements. While establishing necessary conditions, such 'negative' criteria defining when an individual is not regarded as independent can usefully be complemented by 'positive' examples of qualities that will increase the probability of effective independence.

Independent board members can contribute significantly to the decision-making of the board. They can bring an objective view to the evaluation of the performance of the board and management. In addition, they can play an important role in areas where the interests of management, the company and its shareholders may diverge such as executive remuneration, succession planning, 
changes of corporate control, take-over defences, large acquisitions and the audit function. In order for them to play this key role, it is desirable that boards declare who they consider to be independent and the criterion for this judgement.

1. Boards should consider assigning a sufficient number of non-executive board members capable of exercising independent judgement to tasks where there is a potential for conflict of interest. Examples of such key responsibilities are ensuring the integrity of financial and non-financial reporting, the review of related party transactions, nomination of board members and key executives, and board remuneration.

While the responsibility for financial reporting, remuneration and nomination are frequently those of the board as a whole, independent nonexecutive board members can provide additional assurance to market participants that their interests are defended. The board may also consider establishing specific committees to consider questions where there is a potential for conflict of interest. These committees may require a minimum number or be composed entirely of non-executive members. In some countries, shareholders have direct responsibility for nominating and electing non-executive directors to specialised functions.

2. When committees of the board are established, their mandate, composition and working procedures should be well defined and disclosed by the board.

While the use of committees may improve the work of the board they may also raise questions about the collective responsibility of the board and of individual board members. In order to evaluate the merits of board committees it is therefore important that the market receives a full and clear picture of their purpose, duties and composition. Such information is particularly important in the increasing number of jurisdictions where boards are establishing independent audit committees with powers to oversee the relationship with the external auditor and to act in many cases independently. Other such committees include those dealing with nomination and compensation. The accountability of the rest of the board and the board as a whole should be clear. Disclosure should not extend to committees set up to deal with, for example, confidential commercial transactions

3. Board members should be able to commit themselves effectively to their responsibilities.

Service on too many boards can interfere with the performance of board members. Companies may wish to consider whether multiple board memberships by the same person are compatible with effective board performance and disclose the information to shareholders. Some countries 
have limited the number of board positions that can be held. Specific limitations may be less important than ensuring that members of the board enjoy legitimacy and confidence in the eyes of shareholders. Achieving legitimacy would also be facilitated by the publication of attendance records for individual board members (e.g. whether they have missed a significant number of meetings) and any other work undertaken on behalf of the board and the associated remuneration.

In order to improve board practices and the performance of its members, an increasing number of jurisdictions are now encouraging companies to engage in board training and voluntary self-evaluation that meets the needs of the individual company. This might include that board members acquire appropriate skills upon appointment, and thereafter remain abreast of relevant new laws, regulations, and changing commercial risks through in-house training and external courses.

\section{F. In order to fulfil their responsibilities, board members should have access to accurate, relevant and timely information.}

Board members require relevant information on a timely basis in order to support their decision-making. Non-executive board members do not typically have the same access to information as key managers within the company. The contributions of non-executive board members to the company can be enhanced by providing access to certain key managers within the company such as, for example, the company secretary and the internal auditor, and recourse to independent external advice at the expense of the company. In order to fulfil their responsibilities, board members should ensure that they obtain accurate, relevant and timely information. 
OECD PUBLICATIONS, 2, rue André-Pascal, 75775 PARIS CEDEX 16

PRINTED IN FRANCE

(26 2004021 P) ISBN 92-64-01597-3 - No. 535332004 